\title{
The TeChNOLOGY AND ARCHEOLOGY OF CORPORATE LAW
}

\author{
SERGIO GRAMITTO*
}

Some answers to pressing problems in modern corporate law come from the past. Archeology of corporate law excavates ancient laws and language in order to illuminate salient issues in contemporary and future corporate debates. This Article employs an archeological approach to corporate law by analyzing three intertwining legal and organizational technologies. First, it sheds light on the origins and nature of legal personhood and on fundamental questions about the rights of business corporations, such as free exercise of religion. Second, it discusses separation of ownership and control as the feature that constitutes the essential formula of the business corporation model. Third, this Article explores use of artificial intelligence to assist, integrate, or replace human directors.

\section{TABLE OF CONTENTS}

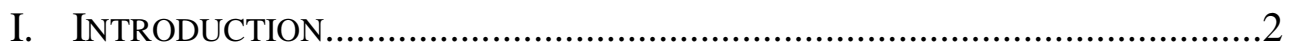

II. ORIGINS, Nature, AND Limits OF Legal Personality AS

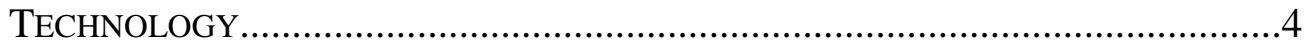

a. The Fundamental Questions on Legal Personality...........................

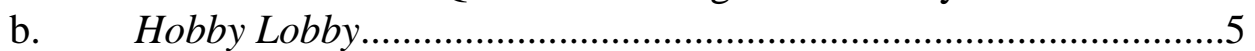

c. The Origins of Legal Personality for Nonhuman Entities...............6

d. Universitas, Corpus, and Persona...............................................

e. Inherent and Granted Rights......................................................

f. Corporate Legal Capacities............................................................10

g. The Past and the Present of Legal Personality...............................11

h. Autonomy from Individuals.........................................................13

i. Rights of Humans and Business Corporations..............................14

j. Persons in a Religious Context..................................................16

k. The Importance of Form and Theory.............................................16

1. The Archeology of Legal Personality..............................................18

III. BUSINESS ORGANIZATIONS BORROWING SEPARATION OF OWNERSHIP

\footnotetext{
* Visiting Assistant Professor and Assistant Director of the Clarke Program on Corporations \& Society, Cornell Law School. I am indebted to Margaret Blair, Kevin Clermont, Mihailis Diamantis, Martin Gelter, Joan Heminway, Claire Hill, James Nelson, Stefan Padfield, Elizabeth Pollman, Stewart Schwab, Andrea Tina, Sidney Tarrow, and Gerald Torres for insightful comments on earlier drafts of this Article. I dedicate this Article to the late Professor Lynn Stout and to our endless conversations over the nature and origins of business corporations. Edoardo Ghio and Christopher Pantuso provided excellent research assistance. All errors are mine.
} 
AND CONTROL FROM MuniCIPALITIES.........................................19

a. Private Capital, Public Services.................................................19

b. The Expansion of Rome and Private Enterprise..........................20

c. The Societas Consensu Contracta and the Business Organizations Landscape before the Societas Publicanorum..............................21

d. Governance Defects of Societates Consensu Contractae and the Pursuit of Separation of Ownership and Control..........................24

e. Archeology of Separation of Ownership and Control as

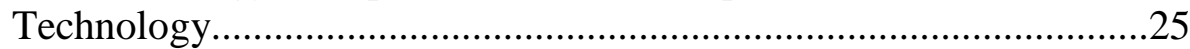

f. $\quad$ Societates Publicanorum as Legal Persons..................................26

g. Societates Publicanorum and Separation of Ownership and

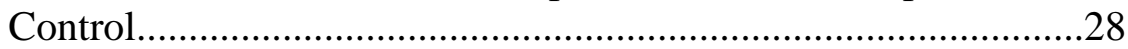

h. A Copernican Revolution in Understanding Separation of Ownership and Control.................................................................29

i. The Inherent Separation of Ownership and Control......................30

IV. The PAst, PRESENT, AND Future OF SEPARATION OF OWNERSHIP AND CONTROL: FROM ROMAN SLAVES TO ARTIFICIAL

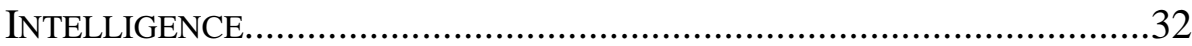

a. The Future of Separation of Ownership and Control and Artificial

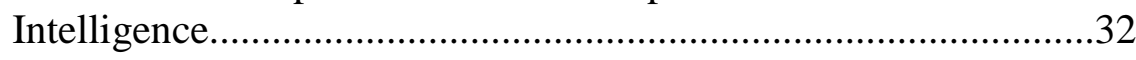

b. Artificial Intelligence In Boardrooms.........................................33

c. Artificial Intelligence as Assistance for Board Directors...............35

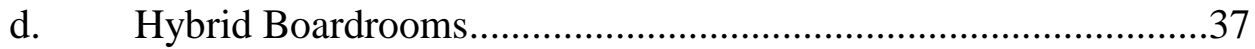

e. Artificial Intelligence Replacing Board Directors........................39

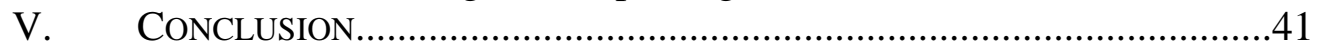

\section{INTRODUCTION}

Corporations have existed as separate legal entities for millennia. ${ }^{1}$ If we want to understand the laws and language governing the development of corporations in human history, we should travel to when the first corporations were created. The first corporations were not business companies but rather cities and towns. ${ }^{2}$ These were the city of Rome and the towns over which it had sovereignty. ${ }^{3}$

\footnotetext{
${ }^{1}$ WiLliam BLACKSTONE, COMMENTARIES ON THE LAWS OF ENGLAND 468 (arguing that Numa Pompilius invented legal personhood for nonhumans.)

${ }^{2}$ See PATRick William Duff, PERsonality In Roman Private LAW 62 (1938) ("If the State is the greatest of Persons and the dispenser of Personality, it is the city which is the most important unit in the history of Roman corporations"); RICCARDO ORESTANO, IL PROBlema DElle PERSONE GIURIDICHE IN DiRITTO ROMANO (1968).

${ }^{3}$ See infra Part II.
} 
The Romans were the first to decide that nonhuman entities could have capacity of action, proprietary capacity, and tortious capacity. ${ }^{4}$ Roman towns and cities could contract, sue, be sued, own assets, bear liabilities, and commit and suffer torts in their own names. ${ }^{5}$ They could act on the same footing as individuals while remaining autonomous from them. ${ }^{6}$ Thus, assets, rights, duties, liabilities, and obligations of towns and cities were perfectly separate from those of their citizens. These nonhuman legal entities could exist and bear their rights and liabilities in perpetuity. ${ }^{7}$ This is how the Romans made the Eternal City eternal. ${ }^{8}$

Unlike natural persons, who bore many rights and duties through natural law, and unlike contemporary corporations, which originate from the action of private parties, the Romans created their corporations through political action. The Romans originally invented legal capacity for cities and towns and extended its application to other nonhuman entities whenever the state had an interest in making them rights-and-liabilities-bearing subjects. This is how the Romans invented corporations, which they dubbed universitates. ${ }^{9}$

Derived from the Latin "in unum vertere," which translates to "to turn a multitude into one," universitas, in contemporary language, would translate to corporation or legal person-and these terms are used interchangeably throughout this Article. However, the Romans never defined legal capacity for nonhuman entities as "legal personality" or "legal personhood," nor did they use "legal person" to refer to nonhuman legal entities.

The Romans refrained from adopting the lexicon of personality for nonhuman entities because the Latin word "person" carried specific connotations predicated exclusively on individuals by virtue of their human nature. ${ }^{10}$ In Ancient Rome, every physically sound human was a person, regardless of their legal capacity. ${ }^{11}$ Ius Naturale - the branch of Roman law that determined rights and duties that living beings have for the sake of being alive-afforded an array of "rights of the personality," such as religious freedom, to any "person." 12 Accordingly, the Romans did not bestow religious

4 See infra Part II(c). See RICCARDO ORESTANO, supra note 2, at 80-81; see also Antonio Guarino, Profilo Di Diritto Privato Romano (1965).

${ }^{5}$ For further discussion on the importance of the use of names to identify legal persons; see also CARLO EMANUELE PUPO, LA PERSONA GIURIDICA (2012).

${ }^{6}$ See BlaCKSTONE, supra note 1. See also PUPO, supra note 5.

${ }^{7}$ See infra, Part II.

${ }^{8}$ See Historic Centre of Rome, the Properties of the Holy See in that City Enjoying Extraterritorial Rights and San Paolo Fuori le Mura, United Nations Educational, Scientific and Cultural Organization, available at https://whc.unesco.org/en/list/91.

${ }^{9}$ See BlaCKSTONE, supra note 1 . The singular is universitas.

${ }^{10} I d$.

${ }^{11}$ Deformed humans were defined as monsters, not persons. See GUARINO, supra note 4 , at 95 .

12 The Ius Naturale is Latin for "natural right" and is understood as the general law 
liberties on nonhuman entities, which were not "persons" since they are not human.

As a result, nonhuman legal entities, though provided with legal capacity, did not enjoy religious liberties, whereas slaves - lacking legal capacity - did. A Roman slave could not possess property but had the liberty to practice religion and participate as a member of religious associations. ${ }^{13}$

In sum, the Romans drew a line between the legal capacities of their corporations and the rights and liberties that persons possessed simply by being human.

By "excavating" the language and the laws that the Romans adopted to address corporations, this Article provides insights and context for understanding and solving salient corporate law issues, including the extension of corporations' rights and the relation between the corporate form and separation of ownership and control, as well as the framework for assessing a rising challenge-how to handle and regulate artificial intelligence in boardrooms.

The argument proceeds in five parts: Part II of this Article investigates the language and laws that the Romans adopted when they invented corporations, and it employs them to provide insights and context for the debate on religious liberties for corporations. ${ }^{14}$ Part III discusses how separation of ownership and control is the mainspring of a corporation's legal personality, rather than its by-product. Part IV offers a primer on the issues that artificial intelligence in boardrooms raises. Part V concludes.

II. ORIGINS, NATURE, AND LIMITS OF LEGAL PERSONALITY AS TECHNOLOGY

\section{a. $\quad$ The Fundamental Questions on Legal Personality}

The question what is a legal person? has received as many answers as what is a human $?^{15}$ In an era where legal persons hold wealth and power comparable to those of nation states, shedding light on their nature and on fundamental questions about their rights is crucial for defining the relations between legal persons and humans.

When legal persons claim "rights of the personality"16 — such as religious

governing all beings. Romans understood the Ius Naturale as a right given to all living things by nature.

${ }^{13}$ See Edgar S. Shumway, Freedom and Slavery in Roman Law, 49 U. PA. L. REV. 636 (1901)

${ }^{14}$ Burwell v. Hobby Lobby Stores, Inc., 134 S. Ct. 2751 (2014).

${ }^{15}$ Rolf SERICK, FORMA E REALTÀ DELLA PERSONA GIURIDICA 83 (1966).

${ }^{16}$ See Andrea Tina, Brief Reflections on Burwell v. Hobby Lobby, Inc. (Supreme Court of the United States, June 30, 2014) from an Italian Corporate Law Scholar's Perspective, 
liberties - two issues come into play. First, understanding what corporations are as legal persons and whether they should enjoy "rights of the personality" is essential for both sound corporate law and a democratic political system. Second, studying whether an expansion of rights of personality for corporations restricts the ability of humans to exercise their personal rights is crucial to regulate the interplay between natural and legal persons. When corporations employ thousands of humans and impose corporately embedded religious beliefs on their employees, these humans ultimately have their religious liberty restricted. It is true that a sole proprietor could also employ thousands of individuals, but because business corporations aggregate assets and investments of myriads persons, their power has a greater impact in restricting liberties of individuals. ${ }^{17}$

The current decade has seen groundbreaking developments regarding business corporations' rights of personality. In Citizen United v. FEC, the Supreme Court ruled that the free speech clause of the First Amendment prevents the government from restricting legal persons from independent expenditures for communications. ${ }^{18}$ Further, in Burwell v. Hobby Lobby, the Supreme Court recognized that for-profit corporations can exercise religion under the Religious Freedom Restoration Act (RFRA) just as human beings can. ${ }^{19}$

\section{b. Hobby Lobby}

Hobby Lobby exists as the perfect case with which to test, both in principle and through application of positive law, ${ }^{20}$ the salience of the formula for legal personality as developed by the Romans. In Hobby Lobby, the Supreme Court held that for-profit corporations qualify as persons "capable of exercising religion" for three reasons. ${ }^{21}$ First, RFRA does not provide context to determine the definition of the term "person." Second, the definition of "person" in the Dictionary Act includes corporations. ${ }^{22}$ Third, the Supreme Court reasoned that extending free-exercise rights to corporate persons protects free-exercise rights of humans "associated with" a corporation,

13 Stato, Chiese e Pluralismo Confessionale 1 (2016).

${ }^{17}$ In addition, if individuals could impose their religious beliefs on legal persons that they create or control, these individuals would be able to multiply their "personal rights."

${ }^{18}$ Citizens United v. Federal Election Comm'n, 558 U.S. 310 (2010).

${ }^{19}$ Hobby Lobby, 134 S. Ct. at 2768.

${ }^{20}$ Positive law is traditionally understood as legal rules enacted by people in a political community and can include constitutions, statutes, and regulations. See Wex Legal Dictionary, Cornell LII, https://www.law.cornell.edu/wex/positive_law.

${ }^{21}$ Hobby Lobby, 134 S. Ct. at 2794.

${ }^{22} I d$. at 2755 . 
"including shareholders, officers, and employees." 23

In addition, the Supreme Court emphasized how merchants who sincerely hold religious beliefs would suffer disparate treatment if they had to forfeit their RFRA (and free-exercise) rights when they "incorporate" the business instead of running it as sole proprietors. ${ }^{24}$

The disparity-of-treatment argument flies in the face of the recognized distinction between the rights of a corporation and the rights of the individuals who compose, or are "associated with," it. It is also logically incorrect. In fact, merchants do not forfeit their RFRA rights when they charter corporations; they are simply prevented from multiplying their RFRA rights by exercising them both as individuals and as "controllers" of a separate subject of rights, behind the mask of the legal person "business corporation."

The definition of "person" in RFRA and in the Dictionary Act, as well as the protection of the RFRA rights of the humans "composing" the corporation through the RFRA rights of the corporation, requires more careful analysis. The discussion that Hobby Lobby raised about the definition of persons who enjoy religious liberties needs to be grounded in the laws and language that the Romans employed when they invented the concept of corporation. In fact, the case is centered precisely on the definition of "person," which is the most salient term in the Latin lexicon that distinguishes human beings from corporations. In addition, the case discusses religious liberties - the most distinctive rights of personality in Roman law since slaves could exercise them notwithstanding their lack of legal capacity but nonhuman legal entities could not.

Analyzing why the Romans invented legal capacity for nonhuman legal entities, what criteria they adopted in defining its content and nature, and what language they employed to describe and regulate their corporations grants us access to an insightful interpretation of the nature and rights of modern corporations and provides an historically informed answer to the questions that Hobby Lobby raises.

\section{c. The Origins of Legal Capacity for Nonhuman Legal Entities}

The Romans, who invented legal capacity for nonhuman entities, never predicated legal personhood upon corporations. Nor did they develop a theory of legal personhood based on the transfer of human, legal, political, or spiritual capacities to nonhuman entities. In fact, although they created the concept of legal personhood for nonhuman entities, the Romans consistently refrained from using the terms "persona" or "personality" to define and conceptualize

${ }^{23} I d$. ("Protecting the free-exercise rights of closely held corporations thus protects the religious liberty of the humans who own and control them.").

${ }^{24} I d$. at 2759. 
the legal attributes granted to corporations. ${ }^{25}$ Rome created the technology that first actualized legal capacity for nonhuman legal entities in order to manage their system of municipal government. The Romans also provided legal capacity to towns and cities in an effort to raise them to the rank of entities in the domain of private law. ${ }^{26}$ Thus, the Roman state evolved the concepts of "corporate ownership" and "corporate action" to make cities and towns subjects of rights and duties. ${ }^{27}$ In fact, it is these conceptions that are arguably the crowning achievements of the Roman government system. ${ }^{28}$

Roman towns and cities were called municipes, which stems from the Latin words "munus" and "capere." Where the former translates to "duty" or "obligation," the latter translates to "to take." It is debated whether the term "municipium" described the relation between a town and its citizens or the relation between towns and Rome as a state. ${ }^{29}$ Regardless of the municipium's exact connotations, the term's etymology and use demonstrates that cities and towns were rights-and-liabilities-bearing subjects. ${ }^{30}$ The Romans called these nonhuman legal entities universitates, as they turned a multitude of people and things into a juridical unit bearing autonomous rights, duties, and liabilities. ${ }^{31}$

\section{d. Universitas, Corpus, and Persona}

The concept of universitas implied at least four legal consequences. First, a universitas had assets, rights, duties, and liabilities in its own name. ${ }^{32}$

${ }^{25}$ See John Dewey, The Historic Background of Corporate Legal Personality, 35 YALE L.J. 655, $666 \mathrm{n.15}$ (1926) ("The admission must be made that there is no text which directly calls the universitas a persona[.']") (quoting Maitland in OTTO VON GIERKE, POLITICAL THEORIES OF THE MIDDLE AGE xviii (1902) (translated and prefaced by Frederic William Maitland); GUARINO, supra note 4, at 97 (arguing that in light of the human values carried by the term "persona," the Romans granted legal capacity-but never "personality" - to nonhuman legal entities).

${ }^{26}$ RudOLF SOHM, THE InSTITUTES OF ROMAN LAW 106 (1892).

${ }^{27}$ See DUFF, supra note 2, at 62 (also arguing that cities were a paramount achievement in Roman corporate law); BASILE ELIACHEVITCH, LA PERSONNALITÉ JURIDIQUE EN DROIT PRIVÉ ROMAIN 106, 182 (1942).

28 William L. Burdick, The Principles of Roman LaW AND Their Relation to MODERN LAw 275-76 (1946); See also Ngaire Naffine, Who are Law's Persons? From Cheshire Cats to Responsible Subjects, 66 MODERN L. REV. 346, 347 (2003) (arguing that creating legal persons is the greatest political act).

29 See GUARINO, supra note 4, at 95-96; BASILE EliACHEVITCH, supra note 27. Cf. GEORGE LONG, Universitas, DICTIONARY OF GREEK AND ROMAN ANTIQUITIES, 1214-17.

${ }^{30}$ Frank Frost ABbott, Municipal Administration IN THE ROMAN EMPIRE 7-8 (1926). SoHM, supra note 26, at 106 (arguing that the City of Rome possessed a combination of capacity to act in the domain of private law and of national sovereignty; Rome also dispensed legal capacity to other cities and towns).

${ }^{31}$ See BlaCKSTONE, supra note 1, at BOOK 1, CHAPTER 18.

${ }^{32}$ On the role of names for recognizing legal persons as autonomous juridical subjects 
Second, the assets, rights, duties, and liabilities of a universitas were separate from those of the natural persons comprising, or "associated with," it. ${ }^{33}$ Third, a universitas could act and interact with humans and other nonhuman legal entities through human delegates. Fourth, humans formed the will and determined the actions and decisions of a universitas according to specific governance models. ${ }^{34}$

In addition to the term "universitas," the Romans used the term "corpus" in the discourse on legal capacity for nonhuman entities. While universitas was a term with normative value that is understood as "legal person" or "corporation," corpus carried a more descriptive connotation. The most common translation of corpus is "body," but understood contextually, the word indicated a group or ensemble of things or people that was perceived as a unit. ${ }^{35}$ For example, mountains were commonly referred to as a corpus as peaks stand out from a common mountainous body. ${ }^{36}$ Universitas and corpus were interconnected notions, where corpus described a multitude of parts constituting a single metaphorical body, and universitas conveyed information about this metaphorical body as an autonomous rights-and-duties-bearing subject.

Roman jurists sometimes used both universitas and corpus to describe the features of a corporation. This poses a problem in determining the nature of some entities, including Roman business corporations- the societates publicanorum. ${ }^{37}$ In fact, celebrated Roman jurist Gaius stated that societates publicanorum had corpus but did not explicitly define these organizations as universitates. In order to understand how Gaius not only explicitly affirmed that societates publicanorum had corpus, but also how he implicitly referred to them as universitates, one must consider how Gaius first asserted that societates publicanorum had corpus, held common estate (arca communis), and acted through human delegates who ultimately represented them (syndici). ${ }^{38}$ Immediately after, he described the attributes of universitates by

\footnotetext{
bearing rights and duties, see PUPO, supra note 5.

${ }^{33}$ With respect to civitates, Gaius explained how public assets do not belong to anyone but to the [civitas] legal person. See GAIUS, THE COMMENTARIES OF GAIUS AND RULES OF UlPIAN, 78 (1885) ("Quae publicae sunt, nullius videntur in bonis esse: ipsius enim universitatis esse creduntur.").

${ }^{34}$ WILLIAM SMITH, Universitas A DICTIONARY OF GREEK \& ROMAN ANTIQUITIES 121417 (1859).

${ }^{35}$ See DuFF, supra note 2.

${ }^{36} I d$.

37 On the scarcity of sources to investigate societates publicanorum, see ANDREAS FLECKNER, ROMAN BUSINESS ASSOCIATIONS (forthcoming), available at https://papers.ssrn.com/sol3/papers.cfm?abstract_id=2472598.

${ }^{38}$ Gaius tells us that the arca communis was a prerogative of societates that had corpus. The arca communis was a common fund/treasure that belonged to a societas publicanorum as a legal entity. It was composed of the initial contributions of the socii and by retained
} 
listing the features that characterize societates publicanorum-for example, the ability of universitates to act through a human delegate and stand in court through an agent (litis defensio). ${ }^{39}$ In other words, Gaius did not expressly refer to societates publicanorum as universitates, but the features of the societates publicanorum that he listed typically defined what a universitas was. Thus, Gaius seemingly asserted a structural connection between the two concepts by bridging the meanings of corpus and universitas with respect to societates publicanorum.

Despite having legal capacity, universitates were not "persons" under Roman law. The word "persona" originally meant "mask," "character," or "individual." 40 In the legal domain, the term exclusively referred to physically sound humans, ${ }^{41}$ regardless of their civic status. ${ }^{42}$ Ius Naturale granted a suite of rights and liberties to every person, regardless of whether they had legal capacity. ${ }^{43}$ These rights and liberties can be defined as rights of the personality. They were considered intrinsic in the human status, not granted by the state. In Ancient Rome, rights of the personality included religious liberties.

As a result, although the Roman state did not recognize legal capacity to slaves, slaves could practice religion and worship the gods. They could congregate - the term "religion" stems from "religare," which translates to "to bind"- - in order to pray and bind themselves to gods by vows and oaths. ${ }^{44}$

\section{e. $\quad$ Inherent and Granted Rights}

As Ulpianus testified, in Ancient Rome the Ius Naturale regarded all men as equal. ${ }^{45}$ Ius Naturale derived from the moral and rational nature of human

earnings. See GAIUS, supra note 33.

39 "The proconsul allows that $[\ldots]$ a third party can defend a universitas in court, as we can observe in private defenses; this is so because, this way, the universitas is better off." See DuFF, supra note 2, at 40 (translating Gaius' writings from 1885).

${ }^{40}$ It is unclear whether the term derives from the latin verb "per-sonare," which meant "to sound through," or from the ancient Greek word " $\pi \rho o ́ \sigma \omega \pi o v$ [prósôpon]," which meant "person," "face," or "mask."

${ }^{41}$ Deformed humans were defined as monsters, not persons. See GUARINO, supra note 4 , at 95 .

${ }^{42}$ Id. at $94-96$.

${ }^{43}$ A number of restraints applied to slaves, but during the Empire, they were at least acknowledged as persons within the sphere of Ius Sacrum. See SOHM, supra note 26, at 109.

${ }^{44}$ See ibid. Ulpianus stated that three sets of laws composed "private law": the law of nature, the law of nations, and the law of the state. The law of nature determined a number of legal institutions and principles, including marriage. See also CARL SALKOWSKY, INSTITUTIONES AND HISTORY OF ROMAN PRIVATE LAW 327 (2008).

45 "Quid attinet ad ius civile, servi pro nullis habentur, non tamen et iure naturali: quia, quod ad ius naturale attinet, omnes homines aequal sunt." See SALKOWSKY, supra note 44, at $168-69$. 
beings. ${ }^{46}$ The ethical principles of the Ius Naturale were rooted in the common nature that humans shared with other living beings and sometimes conflicted with the other two pillars of Roman private law-Ius Gentium and Ius Civile. ${ }^{47}$

Since nonhuman legal entities did not have human nature, the Romans did not call them legal persons and did not endow them with liberties or rights that traditionally characterized moral and rational beings. ${ }^{48}$ The Romans simply, and perhaps more effectively, enumerated and described the legal capacities that the state granted to corporations: capacity of action, judicial capacity, proprietary capacity, and tortious capacity.

Even today, state action is necessary to determine and grant suites of rights and duties attached to legal capacity for both humans and nonhuman legal entities.

Moreover, just like in Ancient Rome, under the modern conception of human right some rights and duties of human beings preexist political intervention and instead exist inherently in the human species. ${ }^{49}$ The suite of rights that human beings enjoy and exercise throughout their lives, however, expand and shrink as they grow, age, and encounter life challenges. ${ }^{50}$ In fact, a state creates some rights, duties, and liberties by political action and acknowledges others by recognizing their preexistence in nature.

In contrast, modern corporations - just like Roman universitates - do not have rights and duties that preexist political action. As a result, legal capacity for nonhuman legal entities exists exclusively as the product of a state's creation and concession of rights and duties. Thus, a corporation's mere existence and ability to bear rights and duties necessarily depends on political action. $^{51}$ Consequently, because they do not possess human nature, corporations do not enjoy the rights and liberties provided by natural law-or as the Romans called it Ius Naturale. ${ }^{52}$

\section{f. $\quad$ Corporate Legal Capacities}

${ }^{46} I d$. at $11-12$.

47 "Privatum ius tripertitum est: collectum etenim ex naturalibus praeciptis, aut gentium, aut civilibus. Ius naturale est, quod natura omnia Animalia docuit: nam ius istud non humani generis proprium, sed omnium animalium . . commune sit." Id.

${ }^{48} I d$. at 327.

49 This is one of the foundations of modern human rights.

${ }^{50}$ It is a fact that just like the "person" in the riddle of the Sphinx, a human's legal capacity "walks on four legs in the morning, on two legs at noon, and three legs in the evening." See SOPHOCLES, OEDIPUS THE KING.

51 David Ciepley, Beyond Public and Private: Toward a Political Theory of the Corporation, 107 AM. POL. SCI. REV. 139 (2013).

52 In the Roman legal system, the concept of "natural law" was understood as "the law shared by all creatures, which is established by Divine providence and remains fixed and immutable." Richard A. Pacia and Raymond A. Pacia, Roman Contributions to American Civil Jurisprudence, 49 R.I. Bus. J. 5 (2001). 
The Romans granted "corporate" legal capacities to nonhuman entities when the object pursued by a group of persons could not be achieved without turning this group of persons into a subject bearing rights and duties. ${ }^{53}$ Typical cases requiring the creation of an entity included capital-intensive enterprises, geographically spread businesses, and projects which completion would take multiple human lifespans. In other words, any projects requiring organizational features that could provide asset lock in, centralized management, capacity to survive the death or will of transient constituencies, and ability to aggregate sufficient assets. Roman "corporate legal capacities" were functionally necessary for achieving objectives of the state, and the Roman corporate formula saw these nonhuman legal entities afforded capacity of action, judicial capacity, proprietary capacity, and tortious capacity. ${ }^{54}$

Capacity of action is the ability to undertake acts that produce legal effects. ${ }^{55}$ Universitates acted through delegates. For example, towns acted through their functionaries or special delegates: actores, curatores, and syndici. Through these delegates, universitates could also exercise their judicial capacity, which was the ability to stand in court, sue, and be sued. ${ }^{56}$

Proprietary capacity is the ability to own assets and bear rights, duties, and liabilities in one's own name. ${ }^{57}$ The Romans carefully distinguished the property of nonhuman legal entities from that of individuals: the proprietary rights of a town were separate from those of the citizens and vice versa. Thus, citizens did not enjoy any rights — not even pro quota - over the assets of the town, and vice versa. ${ }^{58}$

Tortious capacity is connected to both proprietary capacity and capacity of action. Tortious capacity is the capacity to commit torts and potentially incur consequential liabilities. ${ }^{59}$ In a manner that might seem familiar to contemporary corporate lawyers, liabilities that originated from any torts committed by a universitas did not extend to individuals who comprised or

${ }^{53}$ SALKOWSKY, supra note 44 , at 327.

${ }^{54}$ SOHM, supra note 26 , at $140-43$.

${ }^{55}$ SALKOWSKY, supra note 44, at 290; see also SOHM, supra note 25, at 140.

${ }^{56}$ In contrast, slaves, who did not possess legal capacity, had "mere capacity of action" since their actions produced legal results for their owners when advantageous. GUARINO, supra note 4, at 131; SOHM, supra note 25, at 108-09.

${ }^{57}$ SoHM, supra note 26, at 143.

58 "Universitatis sunt non singulorum veluti quae in civitatibus sunt theatra et stadia et similia et si qua alia sunt communia civitatium. Ideoque nec servus communis civitatis singulorum pro parte intellegitur, sed universitatis." CLIFFORD ANDO, LAW, LANGUAGE, AND EMPIRE IN THE ROMAN TRADITION, 148 (2011) (quoting Gaius); see also EMILIO AlbERTARIO, CORPUS AND UNIVERSITAS NELLA DESIGNAZIONE DELLA PERSONA GIURIDICA 112-13 (1933) (arguing that, according to Gaius and Marcianus, assets may belong to "everybody," "nobody," an "individual," or a "city as a legal person.").

${ }^{59}$ SOHM, supra note 26, at 143. 
participated in the universitas.

\section{g. The Past and the Present of Legal Personality}

Because state action through law is necessary for corporations to become subjects bearing rights, duties, and liberties, we refer to such nonhuman legal entities as "legal persons" to distinguish them from natural persons (i.e., human individuals, whose existence does not require political intervention). The formula that provides entities with legal capacity - the suite of rights duties, and autonomy usually reserved for individuals - is dubbed "legal personality." ${ }^{\circ 60}$ Yet legal person and legal personality exist only as linguistic symbols, where normative force carried by their designations exclusively depends on the capacities that a state attaches to them, starting with their capacity to exist. As opposed to individuals, legal persons do not exist in nature.

As linguistic symbols that represent legal capacities, the concepts of "legal personality" and "legal persons" should not be interpreted as manufactured "persons" or "personalities" carrying the same morals, ethics, rights, and duties of human beings. To the contrary, they should be understood as symbols that represent three characteristic features of such entities: a capability to be subject to rights and duties, a suite of subjective rights and duties bestowed by a state, and an autonomy from other natural and legal persons.

The term "legal personhood" arises relatively late. A great deal of credit is owed to Thomas Hobbes for the diffusion of current discourse into concepts such as "legal personality" or "things personated." ${ }^{\prime 1}$ Such linguistic symbols raise a number of interpretative issues, mostly related to the appropriation of the concept of persona. There is often confusion in the contemporary debate over political rights and civil liberties for corporations, as the term "person" may seem to suggest that corporations possess some sort of human dimension. Such a misunderstanding, however, is inconsistent with both the origins of corporations and the precise lexical distinctions originally made by those who invented corporations, the Romans.

Two ideas have contributed significantly to the misconception of corporations as persons. First is the use of "legal person" as a semantic symbol; second is the illusion that when a multitude of human beings are turned into one autonomous subject, this subject ought to derive rights and duties from the

${ }^{60}$ See Floriano D’Alessandro, Persone GiURIDICHE E ANALISI DEL LinguagGio (1988).

61 See Thomas Hobbes, Leviathan: Or The Matter, Forme AND Power OF A COMMON-WEALTH ECCLESIASTICALl AND CIVILL (RETHINKING THE WESTERN TRADITION) (1651). 
humans participating in the juridical subject. ${ }^{62}$ In Hobby Lobby, the Supreme Court seemed to be charmed by this "aggregate theory"-which understands corporations as an aggregation of human beings - when it declared that a legal person "is simply a form or organization used by human beings to achieve desired ends." 63

However, raising corporations to the level of human beings simply because they are the product of aggregations of human beings fails to consider two critical elements. First, the aggregated subjects have heterogeneous components that are not all necessarily human. In fact, many of the participants in a corporation are legal persons themselves; this is evident when we look at the aggregation of shareholders in business corporations. Second, when Hobbes used the word "person" in the acclaimed Leviathan, he was referring to an agent who acts on behalf of "inanimate things" in order to endow them with a purely legal capacity. Hobbes explained that "inanimate things" (such as a town, for example) become "things personated" through reliance upon the authority and legal capacity of a legally capable agent who acts as the human "mask" (persona) of nonhuman entities. ${ }^{64}$

Drawing on the etymology of the Latin word "persona" ("mask"), Hobbes suggested that "inanimate things" obtain legal capacity by virtue of the authority of the agent. Thus, the Hobbesian scheme of legal capacity for nonhuman entities does not stem from a delegation of authority from principal to agent, but rather from the transferal of the agent's legal capacity to the otherwise incapable nonhuman principal. Simply put, Hobbes constructed legal personhood for "inanimate things" on the transferal of the human attributes of the agent to the nonhuman principal. The original use of the terms "legal persons" and "legal personality" referred to the human nature of the agent who then could represent inanimate things. It did not mean that nonhuman legal entities were legal persons because they were "composed" of aggregated human beings. Nor did it mean that they were legal persons simply because they received an array of rights identical to those enjoyed by natural persons.

\section{h. Autonomy from Individuals}

Legal persons are autonomous from individuals in two ways. First, they have autonomous rights and duties. Second, they interact with other subjects in the legal domain on an autonomous footing. Thus they are responsible for their actions and subject to liability for harm their actions may create. The

${ }^{62}$ Margaret M. Blair and Elizabeth Pollman, The Derivative Nature of Corporate Constitutional Rights, 56 WM. \& MARY L. REV. 1673 (2015).

${ }^{63}$ Burwell v. Hobby Lobby Stores Inc., 134 S. Ct. 2751 (2014).

${ }^{64}$ HOBBES, supra note 61. 
Romans summarized the autonomy of nonhuman legal entities from individuals in the principle universitas distat a singulis, which translates to "a legal person is different and distant from individuals participating in it." 65

The Romans specified that individuals have no property rights over a nonhuman legal entity's assets and that individuals cannot be held liable for a nonhuman legal entity's liabilities and vice versa. ${ }^{66}$ Legal scholars refer to this fundamental principle of corporate law as "asset partitioning." ${ }^{\prime}$ Yet asset partitioning is just a by-product of a nonhuman legal entity's autonomy from individuals. All duties and rights - not simply property rights over assets - of a legal person are distinct and separate from those of individuals.

Ultimately, a legal person's autonomy can be explained through the formative mechanics of legal personhood. The state grants legal capacity to nonhuman entities and determines which rights and duties they have. The rights of human beings who comprise a nonhuman legal entity do not permeate into the legal subjectivity of the entity existing as a legal person. In other words, legal personhood is not a mechanism that simply aggregates the rights and duties of individuals. ${ }^{68}$ It follows that individuals cannot multiply their rights and exercise them twice - that is, an individual cannot exercise his or her rights on a personal level and then again on a legal entity level. Furthermore, the human nature of individuals in no way affects the legal capacities of nonhuman legal persons.

Legal personhood is the regula juris through which a state creates new, autonomous subjects capable of acting in the legal domain, and it bestows rights and duties upon them. Philosophically speaking, legal persons are characterized by a form of otherness from the individuals participating in them. This form of otherness translates into the corporate separateness that plays a pivotal role in corporate law.

\section{i. $\quad$ Rights of Humans and Business Corporations}

The original formula was based on three elements. First, universitates were autonomous from individuals comprising them. Second, they could act in the legal domain and bore rights and duties in their own name. Third, they received a suite of powers and duties from the state that enabled them to pursue goals in which the state had a vested interest.

Viewing the facts of Hobby Lobby through the lens of the Roman formula leads to a fairly straightforward conclusion: Hobby Lobby, as a corporation, is

${ }^{65}$ D'ALESSANDRO, supra note 60 , at 59-60.

${ }^{66} I d$. at 60.

${ }^{67}$ Henry Hansmann and Reinier Kraakman, The Essential Role of Organizational Law, 110 YALE L.J. 386 (2000).

${ }^{68}$ D'ALESSANDRO, supra note 60. 
not entitled to RFRA (and free-exercise) rights. First, as a for-profit corporation, Hobby Lobby qualifies as a nonhuman legal entity, and according to the Romans, nonhuman legal entities do not enjoy the rights and liberties that humans inherently enjoy simply by virtue of their humanity. ${ }^{69}$ Under the Roman formula, whether the entity had a for-profit or nonprofit objective and whether the legal person was a closely-held or publicly-held corporation would be irrelevant. ${ }^{70}$ Second, the rights and duties of individuals would be separated from those of the nonhuman legal entities "associated with [them] . . in one way or another."71 The Romans always conceived nonhuman legal entities as autonomous subjects with legal capacity, wholly independent from any individual. In addition, nonhuman legal entities receive legal capacity from a state in order to pursue goals considered relevant by the state as opposed to goals that would magnify the rights and powers of individuals.

Addressing the case according to positive law requires more nuanced reflections. As mentioned, the issue in Hobby Lobby concerned whether forprofit corporations qualify as persons entitled to exercise RFRA (and freeexercise) rights. ${ }^{72}$ RFRA does not define what the term "person" means. The central debate revolves around the question of what "a person's exercise of religion" means. In other words, the Court wrestles with the question of whether the protection of religious liberties should extend to nonhuman legal entities. Rephrasing the question by adopting nomenclature that does not refer to the concept of person assists in clarifying the object of the issue. In fact, doubts and confusion around the RFRA's scope of application arise from the use of the term "legal persons" to refer to nonhuman legal entities. Hence we ask: Does the RFRA apply exclusively to natural persons or does it apply to nonhuman legal entities as well? And further, can nonhuman legal entities even exercise religion?

In attempting to answer these questions, the Supreme Court looked to the Dictionary Act, ${ }^{73}$ which it is required to consult in order to determine "the meaning of any Act of Congress, unless the context indicates otherwise." "74 As a matter of positive law, the most important legal bifurcation is deciding whether "the context indicates otherwise." 75 Justice Samuel Alito, in his majority opinion, emphasized how the Court saw "nothing in RFRA that suggest[ed] a congressional intent to depart from the Dictionary Act definition." ${ }^{.76}$ For purposes of analysis, it does not help that the Secretary of

\footnotetext{
${ }^{69}$ See supra Part II(k).

${ }^{70} I d$.

${ }^{71}$ Burwell v Hobby Lobby Stores Inc., 134 S. Ct. 2751, 2768 (2014).

${ }^{72} \mathrm{Id}$. at 2754.

${ }^{73} \mathrm{Id}$. at 2768 .

741 U.S.C. $\$ 1$.

${ }^{75}$ See id.; see also Hobby Lobby, 134 S. Ct. at 2768.

${ }^{76}$ Hobby Lobby, 134 S. Ct. at 2768.
} 
Health and Human Services (HHS), the government petitioner in the case, "ma[de] little effort to argue otherwise" and explicitly "concede[d] that a nonprofit corporation can be a 'person' within the meaning of RFRA.".77

Instead, the government emphasized the inability of a for-profit corporation to exercise religion altogether. Thus, the focus of the debate was not on the legal attributes of a nonhuman legal entity, but rather on the abilities of nonhuman legal entities. ${ }^{78}$ In fact, HHS recognized RFRA protection for nonprofit corporations while denying it to for-profit corporations. In other words, the distinction offered by HHS did not affect the ontology of nonhuman legal entities but rather just the teleology of nonhuman legal entities. Such an approach has clear ramifications on the definition of the term "person." As the Court observed, the term "person" can be understood as either including exclusively natural persons or including both natural and legal persons, but it cannot include natural persons and a subcategory of legal persons. ${ }^{79} \mathrm{~A}$ distinction based on the teleology of different legal persons misses the mark and lays the groundwork for the extension of the term "person" to nonhuman legal entities, complete with the RFRA protections that accompany the term.

\section{j. $\quad$ Persons in a Religious Context}

As the dissenting opinion points out, an accurate understanding of the term "person" requires first and foremost an analysis of whether "the context indicates otherwise." 80 And in this case, context would seem to "indicate otherwise": under the Romans' understanding, religious liberty is a right of human personality. ${ }^{81}$ It springs from human nature and therefore would belong solely to (physically sound) humans.

If, as the Romans believed, religious liberty springs from human nature as an expression of Ius Naturale and cannot be considered a legal capacity unless explicitly provided by action of the state, it follows that the context of an act

77 Id. at 2756 ('HHS's concession that a nonprofit corporation can be a 'person' under RFRA effectively dispatches any argument that the term does not reach for-profit corporations; no conceivable definition of 'person' includes natural persons and nonprofit corporations, but not for-profit corporations.").

${ }^{78} I d$. at 2755 ("HHS and the dissent nonetheless argue that RFRA does not cover [Hobby Lobby] because they cannot exercise ... religion.”) (internal quotes omitted).

${ }^{79}$ Id. The Court, however, suggested a potential distinction between closely held corporations and publicly held corporations. Id. at 2768-69. This distinction would seem blatantly inconsistent with the determination of the Court that either all or no corporations are "persons." Id. ("No known understanding of the term 'person' includes some but not all corporations.").

${ }^{80} I d$. at 2768 ("[Because] the RFRA itself does not define the term 'person,' [w]e therefore look to the Dictionary Act, which we must consult 'in determining the meaning of any Act of Congress, unless the context indicates otherwise."') (citing 1 U.S.C §1).

${ }^{81}$ See supra note Part III. 
regulating freedom of religion ought to be clear: a state regulation of religion would apply exclusively to human beings, and the term "person" would mean a natural person unless otherwise provided in a statute. On these grounds, the application of positive law excludes any nonhuman legal entity from RFRA rights.

This finding would be an Occam's Razor for the rest of the discussion in Hobby Lobby, as no further arguments or assumptions would be needed. ${ }^{82}$ Nevertheless, it is probably worth pointing two additional flaws in the opinion. First, the majority opinion doesn't distinguish between the corporate form and other organizational models such as sole proprietorships or partnerships. Second, the opinion impliedly but bluntly adopts the "aggregate theory" disregarding the corporate separateness.

\section{k. The Importance of Form and Theory}

The corporate model is based on the irrelevance of its participants' qualities. In fact, the model is largely premised on separation of ownership and control, whereas a partnership model is centered on the personal characteristics of the partners, who select one another with each other's personal characteristics in mind. ${ }^{83}$ The most extreme example of the "intuitus personae" partnership model is the societas consensu contracta, where the personal characteristics and preferences of the members were so relevant that any change in the individual or collective qualities of the partners, or in their inclination to do business, terminated the organization. ${ }^{84}$ In contrast, the corporate form is based on the airtight separation of rights and duties of shareholders from those of the nonhuman legal entity. As such, it should be evident that the choice of organizational form matters significantly. A "personal" and "personalist" organizational model could provide enough derivation of the qualities, beliefs, and personal visions of its members so that the personal beliefs of these partners could permeate the business organization. In addition, the decision-making patterns and liability regime of a partnership are better suited to the personal characteristics or rights that spring from the human nature of the partners. ${ }^{85}$ This is of course obvious for sole

\footnotetext{
82 Occam's Razor is the metaphysical, problem-solving principle that one should refrain from positing arguments or assumptions in the absence of known compelling reasons to do so. See William of Ockham, Stanford Encyclopedia of Philosophy, Section 4.1, https://plato.stanford.edu/entries/ockham/\#4.1 (Aug. 16, 2002).

${ }^{83}$ See infra Part III (c).

${ }^{84} I d$.

${ }^{85}$ As opposed to partnerships where managing partners can bear significant amounts of liability, corporations are often considered "depersonalized" and much less personal than other business forms. See, e.g., Barbara Abatino, Giuseppe Dari-Mattiacci, and Enrico C. Perotti, Depersonalization of Business in Ancient Rome, 31 OXFORD J. LEGAL STUDIES 365
} 
proprietorships too.

With respect to the implied but blunt adoption of the "aggregate theory," the opinion refers to three relations: the relations between merchants and "their" corporations, the relation between controlling shareholders and "their" corporations, and the relation between corporations and their natural-person stakeholders. The opinion interchangeably refers to these three relations when it considers corporations as blanket aggregations of human beings with religious liberties.

The equalization of these three distinct relations creates several issues. First, the corporation is an entrepreneur itself, distinct from the merchants and entrepreneurs "associated with" the corporation. Further, controlling shareholders are erroneously defined by the Court as the "owners" of a corporation. In fact, both in Ancient Rome and in the current corporate world, nobody could own a corporation. ${ }^{86}$ Imposing the religious beliefs of the controlling shareholders or founders on a nonhuman legal entity enacts a hegemonic pattern, which duplicates personal and, in this case, religious beliefs of a handful of powerful individuals through a legal person-something very different from considering the religious and personality rights of all the participants in the corporation. When the religious belief of the majority shareholders or of the founders is imposed on the rest of the humans participating in a corporation, the religious liberties of current and future participants in the corporation get restrained. In sum, recognizing the religious belief of a nonhuman legal entity would reduce the religious liberty of numerous human beings (minority shareholders as well as other stakeholders, including employees) and it would magnify or duplicate the religious rights of one or more founders or majority shareholders.

Finally, this opinion is problematic for an additional reason: it seems to assume that shareholders are necessarily human beings, whereas in reality, shareholders often are nonhuman legal entities (e.g., corporations or hedge funds). It is difficult to address the degrees of separation that divide a human being's beliefs from the religious beliefs of corporations controlled directly by that human being, or controlled by that human being through corporations and other legal persons. In addition, such distinctions would create an asymmetric system, where corporations controlled by human beings are entitled to more rights (including religious liberties) than corporations controlled by legal

(2011).

86 A corporation owns itself. See Lynn Stout, Bad and Not-so-Bad Arguments for Shareholder Primacy, 75 S. CAL. L. REV. 1189, 1191 (2002) ("A lawyer would know that the shareholders do not, in fact, own the corporation."). Although shareholder "ownership" language is often used as a rhetorical device to describe the position shareholders hold in relation to the corporations they hold shares in, shareholders own only types of corporate securities that grant rather limited rights. $I d$. 
persons or, according to the opinion, by the public.

\section{l. The Archeology of Legal Personality}

Throughout the process of creating and regulating nonhuman legal entities, the Romans refrained from labelling these entities "persons" or "legal persons." 87 In fact, "person" and "personality," both words stemming from the Latin "persona," were exclusively used to describe human beings. ${ }^{88}$ This attribution had normative value because personae ("persons") had a set of rights and liberties of the personality that sprung from Ius Naturale and that defined individuals belonging to the human species. ${ }^{89}$ The Romans never attributed these rights and liberties of the personality to corporations, as such rights and liberties were understood as being inconsistent with the nature of nonhuman entities. ${ }^{90}$

Careful consideration of these details is important because language has played a determinant role in shaping the current understanding of what legal persons are. Unfortunately, current nomenclature is at odds with that adopted when corporations were invented and first regulated. The current use of "legal person" and "legal personality" as linguistic symbols facilitates miscomprehension of what corporations are and, perhaps more importantly, what they are not. Excavating the origins of the concept of legal personality and the original Roman lexicon used to describe it allows us to contextualize terms like "person" and "legal person" according to the semantic properties they had when they were introduced to the juridical world. In fact, though it seems unlikely that we could abandon the use of the current legal personality language, it is vital for the relations between business corporations and society that the rights of corporations are not extended in a fashion inconsistent with their nature and purpose and potentially harmful for the rights of individuals. Moreover, having a proper and solid understanding of the original corporate formula allows us to confidently explore innovative legal technologies in the corporate realm.

\section{BUSINESS ORGANIZATIONS BORROWING SEPARATION OF OWNERSHIP AND CONTROL FROM MUNICIPALITIES}

${ }^{87}$ See BLACKSTONE, supra note 1 , at 468.

${ }^{88}$ Once it became apparent that different individuals could take on different legal roles in Roman courts of law, the word became used to describe legal attributes such as rights, duties, and powers.

${ }^{89}$ The two necessary conditions to enjoy such set of rights and liberties were being human and being physically sound.

${ }^{90}$ Such nonhuman entities were understood as lacking the common sense instilled in Roman citizens by virtue of the natural law. 


\section{a. Private Capital, Public Services}

When nation states expand, they sometimes rely on private capital and entrepreneurs to provide public services to new regions and citizens or to build the infrastructure necessary to unify people and lands. Rome and the United States of America are two prominent examples. ${ }^{91}$

Public services and infrastructure building that states outsource to private parties range from collecting taxes to constructing aqueducts, roads, or electric grids. In the United States, private business corporations have provided citizens with a myriad of services since the Revolution. Unlike the United States, however, Roman entrepreneurs did not at first have the corporate form available for their businesses, as the legal landscape in Rome did not offer any organizational models that allowed entrepreneurs to aggregate large amounts of assets and commit them to a project.

In fact, Roman entrepreneurs needed an organizational technology through which they could commit assets and investments to an enterprise. Further, entrepreneurs needed to make these assets and enterprises independent from investors while simultaneously centralizing control over them. In short, what they needed was what we now dub separation of ownership and control. The Roman state, which had a vested interest in having entrepreneurs perform public services, possessed a legal technology that could very much make separation of ownership and control possible: legal capacity for nonhuman legal entities, which we currently dub legal personhood.

Legal personhood, ultimately, was the means through which the Romans could obtain separation of ownership and control and provide their entrepreneurs with an organizational model suitable for large-scale projects. Observing the rationales and processes that led to the creation of business corporations demonstrates how a business corporation is a legal person chartered to conduct business through separation of ownership and control. Thus, separation of ownership and control is inherent in the nature of business corporations just like legal personhood.

\section{b. The Expansion of Rome and Private Enterprise}

Roman entrepreneurs who specialized in the auction of public contracts

\footnotetext{
91 The Roman Res Publica, which lasted from the sixth to the first BC until the rise of Augustus as the first emperor, did not have the economic resources to finance all public works and services. In the fifth century BC, Consul Postumius contracted out the construction of the temples for Demeter, Dionysus, and Kore. Dionysius of Alicarnassus. In the fouth century BC, the censors outsourced feeding of the Geese of the Capitol. This event is famous for raising the alarm when Rome was ransacked by the Gallic troops in 390 BC.
} 
were known as publicans. ${ }^{92}$ The state granted public contracts for a variety of tasks, including infrastructure construction, army equipment supply, mine operation, and tax collection..$^{93}$ Polybius recounts that the public works leased out to publicans inevitably changed over time. ${ }^{94}$ Through the second century $\mathrm{BC}$, the Roman state mainly contracted out the construction of infrastructures. From the first century BC on, publicans shifted their core business to tax farming. ${ }^{95}$ Even the Bible tells of Matthew, prior to becoming one of Jesus' Apostles, serving as a publican helping Rome collect taxes. ${ }^{96}$ In fact, since the parable of the Pharisee and the Publican, publicans had made a name for themselves as tax collectors.

Capital-intensive public works required investments that sole proprietors, as individuals, simply could not afford. The contract to build the Marcian aqueduct, for example, required an investment equal to the total wealth of $\mathrm{M}$. Crassus, supposedly the wealthiest Roman in the age of Caesar and Cicero. ${ }^{97}$ Accordingly, the Roman government had a quandary on its hands, as many of the activities carried out by the publicans were functionally necessary to the Roman state's operation. Publicans needed firms able to aggregate lots of capital, survive changes in the "members" basis, centralize management, and act with third parties on the same footing as individuals.

Prior to the corporation, however, the business landscape in Rome did not offer any organizational model that could satisfy these needs.

\section{c. The Societas Consensu Contracta and the Business Organizations Landscape before the Societas Publicanorum}

92 Ernst Badian, Publicans and Sinners. Private Enterprise In the SERVICE OF THE ROMAN REPUBLIC (1972). See also LONG, supra note 29, at 972 ("Their name is formed from publicum, which signifies all that belongs to the state, and is sometimes used as synonymous with vectigal."). Much of the revenue which Rome derived from conquered countries consisted of tolls, harbor duties, and other tax collection contracts that were sold to the highest bidder. $I d$.

${ }^{93}$ Publicans provided indispensable services while generating sizeable earnings in the process; they were legally protected in their position. See Charles Bartlett, The Publicani During the Roman Empire: The Political Economy of Public Contracts, Money, Markets, Lands, and Contracts, Session Number 2.1. Harvard University.

94 POLYBIUS, Historia, Book 6, Vol. 17 (translated and available at http://perseus.uchicago.edu).

${ }^{95}$ These firms were called societates vectigalis. Vectigalia were taxes in Ancient Rome.

${ }^{96}$ Because we derive our knowledge of Roman law from the late Empire, some sources refer to societates vectigalis instead of to societates publicanorum. They qualify societates publicanorum by the object of their business. In the last part of their existence, closest in time to the Empire, societates publicanorum were understood as farming taxes.

${ }^{97}$ As Badian points out, the contract to build the Marcian aqueduct in the mid-second century AD was roughly 45 million denarii. To put this in context, M. Crassus, supposedly the wealthiest Roman in the age of Caesar and Cicero, had a net worth of 8,000 talents, or 48 million denarii. See BADIAN, supra note 92. 
The publicans needed firms that could both endure beyond the human lifespan and aggregate wealth on a greater scale than any individual citizen. They needed a type of firm that was able to own assets, bear liabilities, and even enter into contracts in its own name. None of the Roman organizational models for business offered those features at the time.

Rather, the original associative form in Ancient Rome depended completely on the qualities, fate, and will of its members. Termed "societas consensu contracta," or societas in short, it was largely similar to the modern partnership in that it was an association between two or more partners-in Latin, socii. ${ }^{98}$ A societas could be formed with the mere consent of one socius, and could be dissolved just as easily. ${ }^{99}$ Unlike a contemporary partnership, the societas consensu contracta agreement did not entail any sort of agency: socii were neither agents of one another nor of the societas, which was not in itself an entity. ${ }^{100}$

The soicetas consensu contracta agreement did not have any legal effect on third parties; rather, it only bound socii to fulfill the obligations among themselves. Nevertheless, socii were obligated to enter into contracts brought under the societas agreement by other socii and were held personally liable for the obligations that arose under the societas agreement. ${ }^{101}$

The Romans used the term "fraternitas" to describe the relationship among socii. As the term and the sensitivity of the relations among socii suggest, the

98 See LONG, supra note 29, at 1049 ("When several persons unite for a common purpose, which is legal, and contribute the necessary means, such a union is Societas, and the persons are Socii.").

99 See W.W. BuCKLAND \& ARnOld D. MCNAIR, ROMAn LAW AND COMMON LAW: A COMPARISON IN OUTLINE 505 (1952); see also LONG, supra note 29, at 1049 ("The contract of Societas might either be made in words or by the acts of the parties, or by the consent of the parties signified through third persons: it required no particular form of agreement."). A societas could be ended at the pleasure of any one of the socii, as any member of the body could give notice of dissolution at any time and immediately upon this notice, the societas was dissolved. Id.

100 See MAX RAdin, HANDBOOK OF Roman LAW 260 (1927). "If a socius borrowed money, the other socii were in no case bound by his contract, unless the money had been brought into the common stock. In fact the dealings of one partner did not bind the other partners, except in such cases as they would be bound independent of the existence of the Societas.” LONG, Societas, supra note 29, at 1049.

${ }^{101}$ By communicatio, the share of profits and losses among partners was considered to be "inside" the societates consensus contractae and arose from the obligations among the socius themselves. The importance of personal nature inherent in the contract is further evidenced by the fact that an individual socius could not convey his membership, neither by contract among living people or by hereditary succession, to another person absent the consent of all socius. See Salvo Randazzo, The Nature of Partnership in Roman Law, 5 Aust J. LEGAL HISTORY 1 (2005). 
concept of fraternitas was based on mutual trust. ${ }^{102}$ The personal qualities of each socius were crucial in forming and keeping alive a societas consensu contracta, and any corruption of the qualities of the socii on a personal or collective level almost invariably resulted in the end of the societas. This would seem obvious for an organizational model in which partners retained control and interlaced their governance rights with those of their fellow socii. ${ }^{103}$

The Romans lived by the principle that "if a man chooses as his partner a careless person, he has no one to blame but himself." 104 Accordingly, the societas provided virtually no asset shielding, as each partner was for the liabilities of their societas. ${ }^{105}$ Further, Roman law made no distinction between the obligations and assets of the societas and those of the socii comprising it. ${ }^{106}$ Consequently, socii could only "protect" their personal assets from liabilities that might arise via the societas and "ensure" continued governability of the societas through a meticulous selection of fellow socii based on personal, behavioral, and social features. ${ }^{107}$ This protection of all socii initial qualities engendered two pivotal consequences. First, no socii could be replaced. Because no one could be made partner with someone with whom they did not wish to be associated, a socius could not transfer his equity interest in the societas to third parties by contract, donation, or inheritance. ${ }^{108}$ Second, the societas could not survive any changes with respect to individual and collective qualities of socii or to the inclination to stay bound. Causes of termination included withdrawal, legal action regarding the societas agreement, loss of liberty of any one socii, loss of civitas without loss of

102 As a purely consensual contract, societas were understood and utilized in Rome as a sort of sociological model that fostered close and enduring relationships amongst the socii comprising it.

103 This notion seems obvious when considered in light of the sociological rationales of community and commitment that influenced why the partnerships of consensual societas were so commonplace in Roman law. New Testament scholar J. Paul Sampley explains that "strong sense of community," "individual self-determination," "quasi-brotherly" relationships, and minimization of "social stratification" were all anticipated benefits of entering into societas. See J. PAUl SAMPLEY, PAULINE PARTNERSHIP IN CHRIST: CHRISTIAN COMMUNITY AND COMMITMENT IN LIGHT OF ROMAN LAW 106-08 (1980).

104 See CAESAR FlaviUs Justinian, THE InSTITUTES OF Justinian (translated by J. B. Moyle) (2009); see also W. W. BuCKLAND AND PETER STEIN, A TEXT-BOOK OF ROMAN LAW: From Augustus to JustiniAn 509 ("Gaius . . gives the reason that a man who takes a careless partner has himself to blame.”).

${ }^{105}$ See Brian M. McCall, The Corporation as Imperfect Society, 36 DEL. J. CORP. L. 509 (2011).

106 See REINHARD ZIMMERMAN, THE LAW OF OBLIGATIONS: ROMAN FOUNDATIONS OF THE CIVILIAN TRADITION 454-56 (1990).

${ }^{107}$ Id.

${ }^{108}$ See RADIN, supra note 100; see also LONG, supra note 29, at 1049. 
liberty, change of family position, confiscation of one's property for conviction for a crime against the state, compulsory sale, voluntary surrender of one's whole property in insolvency, and indigence. ${ }^{109}$

\section{d. Governance Defects of Societates Consensu Contractae and the Pursuit of Separation of Ownership and Control}

For all of the potential benefits that the structure may have carried, the societates consensu contractae did not offer a workable organizational model for Roman entrepreneurs who sought to centralize management and aggregate large amounts of capital. This was due in large part to the fact that the operations of any societas consensu contracta necessarily depended on the action of each socius, as any socius had to provide consent with respect to any given decision. In fact, any socius could threaten to withdraw and terminate the societas at any time. This organizational arrangement created opportunistic behaviors that are commonly referred to as "holdup." 110

In addition, socii could cause the termination of a societas even against their own will. For example, death, defective civil liberties, or insolvency for one socius were all potential causes of termination, even if unintentional. For publicans, however, these potential terminative devices were as threatening to the whole societas as risks of holdup. This is because the greater the number of the socii making up the societas, the greater the chance an unforeseen event could dissolve the societas abruptly. Further, the greater the number of socii involved in a societas, the greater the risk of personal liability any one socius could suffer as a result of obligations brought under the societas agreement. ${ }^{111}$

Socii could only base their expectations and hopes of fair and collaborative behavior on the personal qualities of each other. However, the protection assured by preserving the initial personal qualities and intentions of each socii restricted the ability of societates to aggregate enough assets for capitalintensive economic activities. This ultimately made the societas an unsuitable business structure for long-term projects or geographically wide business endeavors. Societates consensu contractae lacked a number of what are now considered to be essential structural features of properly organized joint enterprises: (i) independent existence, (ii) asset lock-in, (iii) centralized management, (iv) limited liability for participants, and (iv) free transferability of equity interests. ${ }^{112}$

As mentioned, the publicans ultimately sought centralized management,

109 See Zimmerman, supra note 106, at 454-56.

${ }^{110}$ John Armor and Michael J. Whincop, An Economic Analysis of Shared Property in Partnership and Close Corporations, 26 J. CORP. L. 983 (2000-2001).

111 See generally Randazzo, supra note 101.

112 See Antonio GuARINo, SoCIETAS CONSENSUS CONTRACTA 815 (1972). 
fungible investors, and legal personality. This is the formula of the Berle and Means corporation. While a large part of corporate law scholarship centers around the fear of potential agency costs when corporate ownership is separated from control, archeology of Roman law tells us that this separation of ownership and control was ultimately the organizational technology sought out by both entrepreneurs and the Roman state. ${ }^{113}$

\section{e. Archeology of Separation of Ownership and Control as Technology}

Hybridizing the concepts underlying private enterprise and the legal capacity afforded "municipal entities," the Romans created the societates publicanorum. ${ }^{114}$ Testimonial accounts place the use of societates publicanorum before the third century BC, when the Romans fought the Carthaginians for control of the Mediterranean Sea in the Second Punic War. ${ }^{115}$ When a pugnacious and more prepared enemy caused an unexpected increase in the costs of the war, the Roman state was forced to outsource the supply of armies serving in Spain to three separate societates publicanorum. ${ }^{116}$

Widespread use of the societates publicanorum grew significantly until the end of the Res Publica, before gradually losing importance at the beginning of the Empire. Societas publicanorum almost disappeared completely under the Antonine dynasty (96 AD-192 AD) when the Empire replaced them with imperial functionaries. ${ }^{117}$ Because of the Justinian's Corpus Iuris Civilis was issued sometime between $529 \mathrm{AD}$ and $534 \mathrm{AD}$ the time gap prevented such a collection of laws from providing a comprehensive set of provisions that governed the societates publicanorum. In fact, available legal sources scarcely cover the regulation and economic relevance of societates publicanorum. Nevertheless, the societas publicanorum can be investigated thank to public

113 See Martin Gelter, Dark Side of Shareholder Influence: Managerial Autonomy and Stakeholder Orientation in Comparative Corporate Governance, 50 HARV. INT'L L.J. 129 (2009).

${ }^{114}$ Blackstone pointed out that "it has been found necessary, when it is for the advantage of the public, to have particular rights continued, to constitute artificial persons, who may maintain perpetual succession and enjoy a kind of legal immortality. These artificial persons are called bodies politic, bodies corporate (corpora corporata), or corporations." See BLACKSTONE, supra note 1 , at 468.

115 The companies of these publicani, the societates publicanorum, are described by Roman historian Livy. In Ab Urbe Condita, Livy describes how government leaseholding was a well-established business when he details the leasing of supply deliveries to the Roman army in Hispania during the Second Punic War. See Ulrike Malmendier, Roman Shares, in William GoetzManN \& K. GeERT Rouwenhorst, The Origins of Value: The FinANCIAL INNOVATIONS THAT CREATED MODERn CAPITAL MARKETS 31-32 (2005).

${ }^{116}$ Id.

117 Massimo Montanari, La responsabilita patrimoniale nelle societa commerciali dell'antica Roma, RIV. Soc. 1567 (1987). 
speeches, private correspondence, and other literature that allow us to "excavate" the most salient legal features of this organizational form.

Archeology of the regulations governing societates publicanorum is an essential first step before understanding how the model would become the archetype of the modern business corporation.

Although it is hard to select clearly defined criteria that would determine when an organization properly qualifies as a "business organization," the core formula that characterizes the structural mechanics of a business corporation is simpler. A business corporation is a legal person created to conduct business through separation of ownership and control. The features typical of modern corporations include centralized management, asset lock-in, limited liability for participants, free transferability of shares, and independent existence. These features spring from the corporation having a legal personality and are possible largely because of separation of ownership and control.

Understanding the societates publicanorum as the archetype of the modern business corporation is not just an exercise in getting the nature of the societates publicanorum right. A proper comprehension of the model does more than just date the origins of the business corporation much earlier than colonial companies. Rather, understanding the societates publicanorum as the precursor of the modern business corporation sheds light on the role of separation of ownership and control in the corporate formula. This clarification is particularly relevant in the contemporary debate over costs and benefits of corporate separation of ownership and control.

Demonstrating that separation of ownership and control is an essential feature of the business corporation model is a profound finding in the "archeology of corporate law," as such an observation readdresses the ongoing debate over the costs produced by separation of ownership and control.

Acknowledging that separation of ownership and control is to the corporate model what incandescence is to the light bulb changes the understanding of the phenomenon from an effect of the corporate form to a cause of the corporate form. Separation of ownership and control, although producing agency costs, allows business corporations to function just as incandescence, while producing heat, allow a light bulb to emit light. ${ }^{118}$ Heat and agency costs

${ }^{118}$ As described by Lynn Stout, when one considers the economic functions of business corporations and the advantages they provide to civic society and investors, we should compare them to light bulbs. By way of analogy, the economic function of business corporations is comparable to the light emitted by a light bulb, whereas agency costs are comparable to the energy that light bulbs burn to produce light. In the case of light bulbs, the "waste" is enormous; yet the function of light bulbs justifies wasted energy. "Waste" for agency costs in the corporate sector is minimal compared to the overall benefits that the corporate form makes available. See Lynn A. Stout, The Corporation As Time Machine: Intergenerational Equity, Intergenerational Efficiency, and the Corporate Form, 38 SEATTLE U. L. REV. 685, 707 (2015). 
are natural side effects that come with irreplaceable advantages.

\section{f. Societates Publicanorum as Legal Persons}

Societates publicanorum had traits typical of legal persons. The entity could sue and be sued, contract, own assets, and bear liabilities in its own name. The credits and liabilities of the societates publicanorum were separated from any credits and liabilities of equity investors, who were apparently provided some form of limited liability. Further, societates publicanorum had a system of centralized management where only few individuals held governance rights. Societates publicanorum were also able to have, barring some legal actions or the exhaustion of the entity's purpose, ${ }^{119}$ a longer lifespan than any investor. ${ }^{120}$ They also were able to issue a form of transferable equity. ${ }^{121}$ As mentioned, societates publicanorum were able to own assets independent of any individuals comprising it. ${ }^{122}$ In general, the assets of a societas publicanorum formed the arca communis, ${ }^{123}$ which can best be described as the central fund of the business organization. When contributed to a societas publicanorum by individuals, assets immediately ceased being the property of those individuals and instead legally became the

119 The actio pro socio manente societate allowed the societas publicanorum to survive notwithstanding legal action concerning it. "Sometimes, it is necessary to act through the actio pro socio even with the societas continuing to exist, such as when a societas vectigalium was formed, and, in view of the economic activities undertaken, nobody deems useful to withdraw from the company nor the gains of a socius are shared with the others." (D.17.2.65.15 (Paulus 32 ad ed.)).

${ }^{120}$ This distinguished societates publicanorum from societates consensu contractae. "So fully is it the case that a societas is dissolved by the death of a socius that persons cannot even agree at the original formation of the societas that the heir shall succeed to the position of a deceased socius. This, our authority says, is the rule with private societates; but in the case of a societas vectigalis (a societas publicanorum in the tax farming business), if one socius dies the societas continues on, that is to say, always provided that the share of the deceased is given to the heir expressly by the written contract, so that it must be conferred upon him: whether this happens or not, it has to be assessed on a case by case basis. What should be said, in fact, in the case in which the ability of the deceased was the main reason why the societas was formed in the first place, or if the societas could not be managed without the deceased?" D. 17.2.59 pr. (Pomp. 12 ad Sab.).

${ }^{121}$ See infra note 131 and accompanying text.

122 'It is typical for those societies that are granted the right to 'incorporate', either as a collegium or as a societas or in any other form, to have, in the fashion of a state, common property, an arca communis and a common representative, through whom, just like in a state, what needs to be done and what needs to happen for the collective entity, is done and happens." (D. 3.4 .1 pr.-1 (Gai 3 ad ed. prov.)).

${ }^{123}$ In addition to the arca communis, societates publicanorum could own other assets, termed res communes. Res communes included groups of slaves (goods in Roman law), called familiae. (D. 39,4,3,1, Ulp LV ad ed; D. 39,4,1,5, Ulp LV ad ed.). 
property of the societas publicanorum. ${ }^{124}$ Roman politician and lawyer Cicero reported numerous stories about the loss of property rights over assets contributed in a societas publicanorum. ${ }^{125}$ Moreover, as a universitas, a societas publicanorum featured asset partitioning: owners' shielding and entity shielding. Because a universitas had credits and liabilities separate from individuals, credits owed to the universitas were not owed to individuals, and individuals were not liable for the liabilities of the universitas. ${ }^{126}$

\section{g. Societates Publicanorum and Separation of Ownership and Control}

Societates publicanorum featured a centralized management system where the positions of mancipes, magistri, and pro magistri were in charge of operating the nonhuman legal entity. Mancipes were the equity investors who obtained public contracts at the auctions. ${ }^{127}$ Socii associated themselves with the mancipes after the latter obtained public contracts at an auction. ${ }^{128}$ Magistri were those in charge of managing and directing the societas publicanorum during the ordinary course of business. According to Porcius Festus, a Roman official in charge of the financial affairs of multiple provinces, magistri possessed more power than anyone else in the societas publicanorum. ${ }^{129}$ Similar to current board directors, magistri's decisions affected not only the participants in the societas publicanorum but also determined the actions of a societas publicanorum toward third parties. ${ }^{130}$

124 Papinian D. 17.2.82.

125 In In Verrem, a collection of his most famous public speeches, Cicero recounts: "In this public money, o judges, there are three kinds of thefts. In the first place, when the money had been contributed in those companies from which it had been drawn at two percent interest . . . ." (Cic. In Verr. 2,3,70,165). In Epistulae Ad Familiares, a collection of his private correspondences with friends and family, Cicero writes: "At the same time you have to take into consideration that I deposited all the money, that legally came to me, with the publicans at Ephesus." "Simul illud cogitare debes, me omnem pecuniam, quae ad me salvis legibus pervenisset, Ephesi apud publicanos deposuisse." (Cic. Ad fam. 5,20,9). While the two excerpts do not provide terribly specific information about the functioning and regulation of the arca communis, together they suggest that investors lost control rights over any and all assets contributed to the societates publicanorum.

126 "Si quid universitati debetur, singulis non debetur: nec quod debet universitas singuli debent" Dig 3.4.7 pr.1 (Ulp 10 ad ed.).

127 The etymology of the word "manceps" is related to the act of raising the "manus," or hand, during an auction. "Manceps is said to be the one that buys or leases from the people, because he shows by raising his hand that he wants to buy the contract." See Malmendier, supra note 116 , at 36-38.

${ }^{128}$ POLYBIUS, supra note 94.

129 See Malmendier, supra note 116 , at 36-38.

130 "Likewise, it is known that a pact of the magister of the societas can benefit and prejudice (all the partners).” PETER BLAHO, MichAL SKREJPEK, JARMILA VANKOVA, \& JAKU ZYTEK, DIGESTA SEU PANDECTA, 262 (2015). 
Finally participes (or adfines) — distinct from both mancipes and sociiwere equity investors who did not enjoy governance rights but rather only held economic interests and received limited liability for their investment. ${ }^{131}$ Participes were understood as "external" investors who were afforded the ability to trade shares. In fact, societates publicanorum issued transferable shares called partes. ${ }^{132}$

\section{h. A Copernican Revolution in Understanding Separation of Ownership and Control}

Through the archeological study of corporate law, the relationship between the separation of ownership and control and the business corporation model can be examined in an unprecedented manner. In creating the societates publicanorum, the Romans fashioned a model principally structured around legal personality and separation of ownership and control. So too did seventeenth-century Dutch businessmen when they created the Dutch East India Company in direct response to what they believed to be the primary problems of corporate governance at the time. In fact, the creation and subsequent regulation of the Dutch East India Company exist as the quintessential example of the importance of separation of ownership and control. $^{133}$

131 "A particeps is different from a socius: as a matter of fact, a particeps has a certain economic interest and does not participate otherwise, contrary to how a socius participates." CICERO, ÓPERA QUA SUPERSUN OMNIA AC DEPERDITORUM FRAGMENTA, 197 (1833).

132 See Cicero, Pro lege Manilia, Pro Ceacina, Pro Cluentio, Pro Rabirio Perduellionis ReO, Book II, Vol. IV. In Cicero's second speech in In Verrem, he explains that participes usually traded their shares shortly after winning a public contract with their respective societas publicanorum. See, CICERO, SECOND IN VERREM. According to Polybius, in the second century BC, nearly every Roman had an interest in a societates publicanorum. See POLYBIUS, supra note 94. Ancient historian Rostovtzeff theorized that it was possible that the Romans developed some form of financial market. See MiCHAEL RostovtzeFf, ThE SOCIAL AND ECONOMIC HISTORY OF THE ROMAN EMPIRE 31 (1957).

133 David Ciepley, Member Corporations, Property Corporations, and Constitutional Rights, 11 THE L. \& ETHICS OF HUMAN Rights 31. Ciepley recounts that at the time of creation of the Dutch East India Company, shareholders lacked any semblance of control rights, and their investments were locked in for a period of exactly ten years. While shareholders retained the ability to sell their shares on the secondary market if they found themselves unhappy with the management of the corporation or found themselves in need of liquidity, they had very little voice over the direction of the corporation and lacked tools to control the board of directors. This structure was based on a perfect separation of ownership and control. However, the board of directors of the company did not consider such a model of ownership and control sufficient. Right before the term for restitution of equity contributions, the board of directors of the Dutch East India Company decided that equity contributions of equity investors would be transformed into permanent capital and would not be refundable to shareholders. Shareholders were substantially expropriated of any rights 
Excavating corporate law provides evidence that separation of ownership and control is essential for the corporate form. It is the mainspring (and not a by-product) of business corporations as legal persons-quite a Copernican revolution for the way we understand corporations.

\section{i. The Inherent Separation of Ownership and Control}

A general principle that characterizes the corporate model is the way in which control is removed from a corporation's constituents and centralized in the hands of individuals appointed for specific roles. This has historically been the approach taken in the setting up of municipalities, churches, and monasteries. With respect to the history of business corporations, however, this centralization of power requires the separation of control from those who hold an economic interest in the business - a phenomenon we dub separation of ownership and control. Once again, the lexicon could facilitate misunderstandings: the concept of separation of ownership and control seems to refer to a phenomenon in which "owners" of some goods are deprived of their "ownership rights." Yet the concept of ownership over a legal person which is afforded legal capacity is logically flawed. In fact, since the invention of corporations, autonomy from individuals has been a characterizing feature of legal personhood. In addition, such a misconception is legally incorrect, because a legally capable subject cannot be owned by another subject. Conversely, Roman slaves could be owned and traded precisely because they did not have legal capacity.

Distinct from other legal persons, business corporations allow some of their constituents to gain operational control, by acquiring shares in their stocks, without any process of selection and specific appointment to that task.

When a controlling shareholder takes control over a corporation, something unusual, at least in the case of traditional legal persons, happens: ownership and control cease being separated. Remaining shareholders, as well as the nonhuman legal entity itself, become subject to the control of a person neither selected nor elected for such a role, whereas board directors are. An analogous situation would present if a citizen was permitted to run a town, without being elected to any such position in municipal government, simply by virtue of that citizen paying more taxes than any other citizen. This phenomenon is atypical for legal persons. In fact, the Romans incorporated towns to make them independent from transient constituents and designed processes for delegating control over towns to specifically selected individuals.

over their initial contributions but refrained from protest as the board of directors declared a dividend of $162.5 \%$ - essentially refunding each shareholder their respective contribution in addition to paying a $6.25 \%$ annual return on all investments. 
Robust literature articulates how empowering shareholders ultimately creates more problems for corporate governance than it solves. This notion is further supported by common sense. Having a process in place to select and elect those in control of any entity and affording individuals the ability to cast a vote in such a process are paramount requirements in almost any properly functioning collective system.

The Roman adage regarding blaming none other than yourself when you select the wrong partner would seem to be just as applicable in this context as in the partnership system. In contrast to partners in a partnership, however, shareholders cannot blame themselves when they are superseded and their interests essentially fall under the control of unelected or undesired controlling shareholders. While shareholders foot some of the blame for rogue boards of directors, which they have a direct role in selecting, they do not share similar blame in situations regarding other shareholders assuming control. Moreover, in systems as complex as business corporations where heterogeneous interests and investments intertwine, separation of ownership and control protects specific investments of all stakeholders. In fact, separation of ownership and control allows super-partes decision makers to attract and retain specific investments and to make them coexist. ${ }^{134}$

Despite the literature challenging the positive tradeoff in separating ownership from control causes, fiduciary duties for directors in boardcontrolled corporations are usually sufficient to ensure relatively sound corporate governance.

The traditional corporate governance model, complete with a board of directors owing fiduciary duties to the corporate entity and the protection afforded to directors by the business judgment rule, generally satisfies the goal underlying separation of ownership and control. This allows business corporations to take on projects that require more than a lifespan and net worth of an individual.

However, human directors can make human mistakes. They can make poor decisions; they can suffer the pressure of markets or shareholders; they can be attracted by distorted incentives; they can shirk; and they can steal. Against this backdrop, advances in technology, particularly artificial intelligence, are often regarded as hopeful solutions to imperfect human governance.

Artificial intelligence, commonly referenced as AI, is prospectively tasked with overcoming and correcting the risks that seem almost inherent in human directors. The next part of the Article discusses how adopting artificial intelligence programmed to be loyal to the corporate legal entity, careful in its decision-making, and respectful of the law could potentially minimize agency costs. It also detects the issues that employing AI in boardrooms raises.

\footnotetext{
${ }^{134}$ Margaret M. Blair \& Lynn A. Stout, A Team Production Theory of Corporate Law, 85 VA. L. REV. 247 (1999).
} 
Once again, the Roman law and organizational technologies are the backdrop against which employment of intelligence without legal capacity for running business is investigated in this Article. Romans entrepreneurs used to organize their a joint enterprise by appointing a commonly owned slave to run the business and manage the assets instrumental to it.

IV. THE PAST, PRESENT, AND FUTURE OF SEPARATION OF OWNERSHIP AND CONTROL: FROM ROMAN SLAVES TO ARTIFICIAL INTELLIGENCE

\section{a. The Future of Separation of Ownership and Control and Artificial Intelligence}

Because separation of ownership and control is inherent in business corporation models, and because independent mediating hierarchies prove to be in the best position to allocate corporate resources, artificial intelligence could be the technological answer to concerns over agency costs. Artificial intelligence would allow a corporation to benefit from separation of ownership and control, while providing investors with all of the protections that intelligent, careful, and virtually unbiased decision makers can guarantee.

Artificial intelligence is a simulation of natural intelligence performed through algorithms, machines, and computer systems that ultimately strive for the performance of actions, typically reserved for humans, with the best possible outcomes. ${ }^{135}$ AI perceives the environment in which it is acting, takes all available data from the world, and stores it so it can later be accessed. Artificial intelligence then makes decisions by comparing new data against old data $^{136}$ and ranking the outcome of its decision against other possible outcomes. By doing so, AI attempts to learn lessons and inform its future decisions. ${ }^{137}$ In short, artificial intelligence reasons and self-corrects.

The presence of artificial intelligence in boardrooms, however, raises a number of obvious moral and legal issues. A general concern coincides with the risk and fear that as artificial intelligence evolves over time, such intelligence could evolve in some fashion dangerous to the human species. ${ }^{138}$

\footnotetext{
135 See GeOrge F. Luger, Artificial Intelligence: Structures and Strategies FOR COMPLEX PROBLEM SOLVING (2009).

136 See David L. PoOle \& Alan K. MackWorth, Artificial Intelligence: Foundations OF COMPUTATIONAL AGENTS (2017).

${ }^{137}$ Ibid.

${ }^{138}$ Nick Bostrom, Superintelligence: PATHS, DANGERS, StRATEGIES (2014).
} 
A number of research centers are currently studying the risks and dangers that artificial intelligence poses in an effort to control and reduce such problems, before its widespread adoption. ${ }^{139}$ Moreover, the development of truly intelligent AI would mean developing a form of artificial consciousness. ${ }^{140}$ Consciousness carries with it the capacity for emotions, which on its own poses the moral question of whether artificial intelligence can suffer. ${ }^{141}$ Thus, humanity is facing the dilemma of whether to create a super-intelligent AI, given worries that such a creation could be vulnerable to suffering or could even prove hostile toward humanity. ${ }^{142}$ As this Article draws an analogy between how the Romans employed the use of slave intelligence for decisionmaking and the incumbent possibility of future use of artificial intelligence in corporate boardrooms, it is worth cautioning that should artificial intelligence ever evolve as a conscious system subject to the command of humans, there is a risk of obtaining a most undesirable result. Technological advances could establish, through the employment of artificial intelligence, a pattern of use reminiscent of slavery in Ancient Rome. The suggestions posited in this Article should be considered only if the creation of such an undesirable result can be positively excluded from the calculus. Otherwise, the development of artificial intelligence should be abandoned altogether.

\section{b. Artificial Intelligence in Boardrooms}

Artificial intelligence has already been used in a number of fields, including medicine and legal practice. For example, IBM's Watson for Oncology is an artificial intelligence machine used by physicians in determining possible cancer treatments. ${ }^{143}$ Further, LawGeex AI is a contractreview platform that supposedly brings to light risks in nondisclosure agreements in a method "more accurate than [human] lawyers."144

139 Sander Beckers, AAAI: An Argument Against Artificial Intelligence, The AAAI-17 Workshop on AI, Ethics, and Society WS-17-02 2017 (naming a number of centers, including the Center for Human-Compatible AI, the Machine Intelligence Research Institute, OpenAI, the Future of Humanity Institute, and the Foundational Research Institute).

140 Ibid. at 2.

${ }^{141}$ See BOSTROM, supra note 138.

142 See Beckers, supra note 139. Beckers warns that without a sound theory of intelligence that can be used to assess AI, it would be difficult to determine when and how AI can be considered more intelligent than humans. The Author makes the example of social skills. Ibid.

${ }^{143}$ Jessica Kim Cohen, Can AI Improve Cancer Care in Remote Areas? 3 Questions with Dr. Andrew Norden of IBM Watson Health, Becker's Health IT and CIO Report (Aug. 29, 2017), http://www.beckershospitalreview.com/artificial-intelligence/can-ai-improvecancer-care-in-remote-areas-3-questions-with-dr-andrew-norden-of-ibm-watsonhealth.html.

144 LawGeex, Artificial Intelligence More Accurate Than Lawyers for Reviewing 
Corporations and investment companies are acknowledging the potential benefits of artificial intelligence as well. While artificial intelligence can be used in boardrooms simply to assist human directors with making decisions, it also has the potential to replace human directors entirely.

In 2014, venture capital firm Deep Knowledge Ventures introduced a machine-learning algorithm called Validating Investment Tool for Advancing Life Science (VITAL) into its board of directors. The firm boasted that VITAL could analyze financial trends and understand financial statements, among other important corporate documents. ${ }^{145}$ The press that covered VITAL's introduction into the Deep Knowledge board of directors emphasized how VITAL could vote on investments but could not technically qualify as a board director. Much of the press coverage asserted that board directors owe duties to a corporation - including duties inherent in overseeing the firm-and that VITAL was not programmed to perform these duties. Further, the press coverage reported how membership on a board of directors entailed "responsibilities that [VITAL was] unable to legally be assigned (or insured for)." 146

In fact, although personhood for autonomous machines is a priority of policy makers, artificially intelligent machines currently do not have legal personality. ${ }^{147}$ Therefore, they cannot be subjects of rights and duties, including corporate fiduciary duties.

The Romans developed an organizational model for business based on hired intelligence without legal personality that resembled the adoption of artificial intelligence in boardrooms. Instead of using AI, Roman entrepreneurs co-owned highly educated slaves and granted them certain assets to engage in a form of collective business called negotiatio per servos communes cum peculium. In fact, in Ancient Rome, slaves could be purchased and co-owned just like goods. ${ }^{148}$ Many slaves had a surprisingly high level of education and

Contracts, PR Newswire (Feb. 26, 2018), https://www.prnewswire.com/newsreleases/artificial-intelligence-more-accurate-than-lawyers-for-reviewing-contracts-newstudy-reveals-300603781.html.

145 See Rob Wile, A Venture Capital Firm Just Named an Algorithm to Its Board of Director: Here's What It Actually Does, Business Insider (May 13, 2014), http://www.businessinsider.com/vital-named-to-board-2014-5.

146 See Monica Goyal, Hong Kong VC firm appoints AI to Board of Directors, ITBusiness.ca (May 16, 2014), https://www.itbusiness.ca/blog/hong-kong-vc-firm-appointsai-to-board-of-directors/48815.

147 See European Parliament resolution of February 16, 2017, with recommendations to the Commission on Civil Law Rules on Robotics 3 (2015/2103(INL) (recommending that autonomous machines, as "limited legal persons," should have an array of duties, including being subject to legal actions and carrying adequate insurance). The European Parliament does not enact laws; it makes recommendations.

${ }^{148}$ See Abatino et al., supra note 85. 
impressive business acumen. ${ }^{149}$

Business corporations have legal capacities similar to those had by the coowners of a Roman slave, where neither Roman slaves nor artificial intelligence had or would have legal capacity. In modern corporate law, a lack of legal capacity for artificial intelligence would lead to a number of directorial shortcomings. In fact, AI would lack capacity to hold office, agency, and authority by which to bind the corporation toward third parties. Moreover, AI would be unaccountable. Roman law and business practice, with respect to slaves, offered solutions that attempted to deal with problems regarding slaves' lack of legal capacity. However, the Roman solutions would not address the additional problem of unaccountability: the relationship between Roman masters and slaves was largely characterized by a system of punishments and incentives, including manumission, that simply would not be workable in terms of potential AI corporate directors.

Artificial intelligence in boardrooms can be conceived in three different forms, each with distinct legal and organizational issues. AI could be employed for assistance to human directors, as integration to human directors, or as replacement of human directors altogether.

\section{c. Artificial Intelligence as Assistance for Board Directors}

Supporting directors' decisions with artificially intelligent machines capable of processing large sets of data in extremely short time would be the simplest employment of artificial intelligence in corporate boardrooms. Artificial intelligence can analyze financial and industrial information, competitor data, social media sentiments toward the firm, and all sorts of additional information. As such, AI can supplement knowledge already held by human directors and can simply make recommendations in situations where time is a critical factor. This arrangement is already utilized in other highly professional and technical settings. For example, Watson for Oncology takes only two minutes to process patient information regarding types and stages of cancer, states of body functions, and fitness levels of different genetic profiles in order to make recommendations about treatment protocols in situations where a team of humans doctors would require at least a day to process such information. ${ }^{150}$ By analogy, artificial intelligence could help directors make decisions when outpouring information needs to be processed in a short time. ${ }^{151}$ Such assistance could be particularly helpful, for example, in corporate

149 See S. L. Mohler, Slave Education in the Roman Empire, 71 TRANSACTIONS AND Proceedings of the American Philological Association 262 (1940).

${ }^{150}$ See Akshaya Kamalnath, Rethinking Liability and Licensing for Doctors in the Era of AI: Insights from Company Law, 11 AsIA PAC. J. OF HEALTH L. \& ETHICS 33 (2018).

${ }^{151}$ Akshaya Kamalanth, Artificial Intelligence in Corporate Governance (paper on file 
takeover situations, when timing is of the essence.

In Delaware, human directors who rely in good faith upon opinions elaborated by artificial intelligence might be able to shield their decisions through $\S 141(\mathrm{e})$ of the Delaware Corporate Code. ${ }^{152}$ In order for protection under $§ 141($ e) to be applicable, however, Delaware Corporate Code requires that opinions on which human directors rely come from a "corporation's officers or employees, or committees of the board of directors, or by any other person as to matters the member reasonably believes are within such other person's professional or expert competence and who has been selected with reasonable care by or on behalf of the corporation." "153 Though the norm would not seem to prevent the individuals listed in the provisions from using artificial intelligence to assist in forming their opinion, but it seems that board directors might be able to call for $\S 141(\mathrm{e})$ protection exclusively in cases where subjects listed in $\S 141(\mathrm{e})$ operate and fully dominate the AI tool and ultimately exercise their personal judgment.

Upon these grounds, artificial intelligence might provide a safe harbor for human director decisions only through the accountability of the subjects listed in $\S 141(\mathrm{e})$, whose opinions ultimately qualify as $\S 141(\mathrm{e})$ opinions because they come from fully capable and accountable natural persons. Such a possibility would have at least two consequences. Potentially, directors could find a way to protect their decision under $\S 141(\mathrm{e})$, even in situations where a time crunch would have otherwise prevented the subjects listed in $\$ 141(\mathrm{e})$ from granting an opinion to board directors. But it is uncertain whether the subjects listed in $\$ 141(\mathrm{e})$ could be considered to have followed a due decisionmaking process when they simply rely on AI advice, especially when they had limited time for collecting information and formulating their opinion. Second, if directors defer all risky decisions to artificial intelligence through the $\S 141(\mathrm{e})$ process, an accountability issue would arise: AI does not have legal personality, does not own assets, and is not accountable. When AI provides an opinion, directors could not simply channel it; in fact, directors are required to exercise their personal judgment, and an AI opinion itself is not even a $\$ 141(\mathrm{e})$ opinion. In other words, an opinion provided by an AI machine is not a $§ 141(\mathrm{e})$ opinion and would not grant protection.

At the same time, it might be challenging for board directors to disregard or override an opinion provided by "super intelligent" artificial intelligence. Human directors may feel overly compelled to "comply" with artificial intelligence suggestions; human directors may also feel compelled to "explain" why they chose to disregard entirely, or deviate from, opinions posited by artificial intelligence. Pressure to explain why they disagree with artificial

with the author).

152 DGCL $\$ 141(\mathrm{e})$.

${ }^{153}$ DGCL $\$ 141(\mathrm{e})$. 
intelligence could ultimately affect a director's ability to exercise independent judgment when making a decision. While it is true that directors already face the possibility of deviating from " $\$ 141(\mathrm{e})$ opinions," when such opinions come from highly intelligent AI, even if not $\$ 141(\mathrm{e})$ opinions, there could psychologically be more of a challenge to overcome before deciding to eschew the AI machine's suggestion. Moreover, pressure to explain such failure to listen to AI suggestions could become even more compelling if the judicial systems were to begin recognizing the particular relevance artificial intelligence could play in corporate decision-making processes.

\section{d. Hybrid Boardrooms}

The second option would see an integrative board of directors, composed of a mix of AI directors with traditional flesh-and-bones directors. Although artificial intelligence would not require any sort of anthropomorphism, a quick look at Hanson Robotics' Sophia, which has already become a cultural icon, gives some sort of idea as to what such robotic directors might look like. ${ }^{154}$ Sophia was named "the world's first United Nation Innovation Champion by [the] United Nations Development Program and will have an official role in working with [the] UNDP to promote sustainable development and safeguard human rights and equality." "I55 In discussing the future of artificial intelligence that Hanson Robotics regards as "genius," 156 David Hanson believes "that three distinctively human traits must be integrated into the artificial intelligence of [such] genius machines: creativity, empathy, and compassion." 157

Sophia's anthropomorphic appearance and humanlike compassion help her to both look and feel human. Because of this, referring to her as another human does not require any strong imaginative effort on the part of other directors in a board meeting. Further, someone might suggest that AI directors could make the best decision makers because they could exhibit the most desirable traits of human directors: loyalty, diligence, and respect of the law. In fact, if we were to agree that a main function of a corporate board of directors is to mediate hierarchies within the business corporation, ${ }^{158}$ two things about artificial intelligence directors could prove true. First, they could outperform many humans in processing the almost never-ending stream of information regarding virtually any and all specific investments, risks, opportunities, and

${ }^{154}$ Behind the Scenes: How Sophia Works, Hanson Robotics, www.hansonrobotics.com/how-sophia-the-robot-works-goertzel.

${ }^{155} \mathrm{Id}$.

${ }^{156} I d$.

${ }^{157} \mathrm{Id}$.

${ }^{158}$ See Blair \& Stout, supra note 134. 
strategies. Second, AI could come to board meetings unbiased and without an agenda (barring, of course, skewed programming by any original programmers and developers). ${ }^{159}$ Moreover, as pointed out by Akshaya Kamalnath, robot directors could, by bringing alternative ideas to the table, enhance a plurality of views in boardrooms. ${ }^{160}$ Such an addition to meetings would ensure that diverse perspectives would be considered in the whole decision-making process, which in turn could lead to better outcomes. ${ }^{161}$

However, a hybrid boardroom-made partly of human and partly of AI directors - could pose at least three problems. One issue regards the authority and capacity of AI to hold office. Another concerns the pressure to conform to decisions made by AI. The last one consists of the emergence of a form of asymmetric accountability. In fact, it is debatable whether AI directors could even be initially appointed as members of a board of directors and whether they could exercise any authority to bind the corporation with third parties.

In general, being appointed as board directors presupposes legal capacity. A board director necessarily has to be subject to certain rights and duties and needs basic capacity of action, proprietary capacity, tortious capacity, and contract capacity. In addition, positive law often requires board directors to satisfy specific criteria and to observe specific restrictions. Delaware's $\S 141$ (b), for example, requires directors to be natural persons. Thus, AI directors would certainly need legal personality, but, depending on the requirements set forth in specific jurisdictions, legal personality may simply not be sufficient for AI to hold a position in a boardroom - this would be the case under current Delaware law.

Similarly to situations where artificial intelligence only assists human board directors, in cases where human directors were integrated with robot directors, natural persons acting as board directors may feel compelled to conform with any opinions asserted by super-intelligent machines. In other words, deviations from the opinions of AI directors may be difficult for fleshand-bones directors to justify. Moreover, assuming that AI directors were allowed to compose any sort of committee able to provide opinion with shielding force similar to those of $\$ 141(\mathrm{e})$, human directors would receive protection from opinions provided by unaccountable AI directors, thus creating an accountability void.

In fact, assuming the hypothesis that AI board directors could hold office without legal personality, only human directors would be exposed to liability vis-à-vis the corporation and third parties. But even if AI directors were

159 Raghuram G. Rajan \& Luigi Zingales, Power in a Theory of the Firm, 113 QUARTERLY J. OF ECON. 387 (May 1998).

${ }^{160}$ Akshaya Kamalanth, supra note 151

161 See STEPHEN M. BAINBRIDGE, THE NEW CORPORATE GOVERNANCE IN THEORY AND PRACTICE 82-94 (2008) (citing numerous experimental studies on the issue). 
afforded legal personality (now assuming that they could hold office without being natural persons), they would not be accountable. Lacking a sentient body, property, consciousness, or sense of morality, AI directors cannot be properly held accountable, as they are not driven by the same human desires, ambitions, and morality that guide natural persons. As Lord Barlow put it, a legal person has "no soul to be damned, and no body to be kicked." 162 In fact, unless AI directors stood to gain or lose anything, they would not have any sort of care or concern if they lost their property or set into effect events causing D\&O insurances to pay money out to third parties. On these grounds, only human directors would be accountable in hybrid AI-human director boards. This would create decision-making dynamics where human directors could likely conform their opinions to the opinions of super-intelligent AI directors, but only human directors would be accountable.

\section{e. Artificial Intelligence Replacing Board Directors}

The third and most radical option would be replacing an entire board of directors with one or more artificially intelligent directors. Within this option there are two possibilities: (1) using one AI machine to replace the entire board of directors, or (2) appointing a number of different AI directors. Both possibilities are workable, but a board comprised of multiple AI directors would allow a corporation and its shareholders to appoint directors manufactured by different companies and laboratories and preserve plurality in decision-making. This would enhance diversity of perspectives and probably reduce risks connected to potential programming bugs or malfunctions of a group of AI directors assembled and programmed by one company.

Replacing human directors with artificial intelligence presents legal and organizational issues similar to those discussed in the case of hybrid boardrooms, but they could be even more extreme. First, AI directors would lack any semblance of legal personality and certainly are not understood as natural persons (regardless of how realistic they may look or how compassionate they may seem). Thus, they could not be appointed to a board, they could not be granted authority to bind the corporation with third parties, they could not bear fiduciary duties, they could not be exposed to liability, and they would not be held accountable.

The Romans faced similar organizational shortcomings in the setting up of their negotiationes per servos communes cum peculium. When adopting the peculium model, Roman citizens delegated the management of a bundle of

162 Edward, First Baron Thurlow 1731 -1806, quoted in J.C. Coffee, Jr., "No Soul To Damn: No Body To Kick”: An Unscandalized Inquiry Into the Problem Of Corporate Punishment, 79 Mich. L. Rev. 386. 
assets organized for a single business to a slave who did not have legal capacity. If slaves, similar to artificially intelligent decision makers, were not considered to be legal persons, they theoretically would not have the capacity to act as agents of a principal-namely, slaves co-owners and corporations. Analogously, they would not be able to make decisions and interact with their principals or third parties. Yet, Roman slaves were tasked with making decisions regarding the business and the assets ("peculium"), contracting with third parties, and interacting with their owners.

The ancient model anticipated many key issues of futuristic AI boards of directors. The Romans were able to solve some of these issues without granting legal personality to slaves. They found a legal solution in the dominica potestas - the property rights that co-owners had over a slave and a peculium. Because both the slave and the peculium were legally understood as property of their co-owners, the slave, as property, had the capacity to enter into transactions affecting the peculium. Dominica potestas created a form of de relato legal capacity for the slave, which was a mere extension of co-owners' legal capacity. In fact, through the potestas, a slave essentially bore a sense of derivative legal capacity from his master. ${ }^{163}$ If modern board directors did not need legal personality to hold office, the Roman solutions may offer guidance regarding how to address artificial intelligence's lack of legal capacity and authority.

Although the Ius Civile allowed co-owners to act indirectly through a slave, it did not thoroughly regulate the legal effects a slave's actions ultimately had on the co-owners. A general framework regulating the legal effects of a slave's actions was offered by the combination of the Ius Civile and traditional praetorian remedies. ${ }^{164}$

Because slaves did not have legal personality, the law governed profits and losses for the co-owners in a markedly asymmetric fashion. A slave's coowners acquired all the rights and profits arising from the peculium, while remaining largely shielded from the corresponding liabilities. (Analogously, this policy would imply that a business corporation could not be liable for any actions of AI directors - a regulation too one-sided to ever be workable.) More precisely, co-owners' protection from liabilities depended on the characteristics of the mandate to the slave and of the business. Generally, Ius Civile protected slaves' co-owners from any liabilities stemming from transactions entered into by slaves. However, praetorian remedies introduced some principles to counter this blanket protection from the Ius Civile: praetorian remedies allowed for creditors to go after the personal assets of coowners under certain circumstances. First, when co-owners consented to a specific transaction or project, they were unlimitedly liable for losses arising

\footnotetext{
163 See SALKOWSKY, supra note 44, at 170.

164 See Abatino et al., supra note 85.
} 
from within the scope of these transactions or projects (actio institoria and actio exercitoria). ${ }^{165}$ Second, the actio de in rem verso provided that co-owners had to return profits originally drawn from a transaction that eventually caused liabilities if a situation was created where the assets of the peculium were not enough to satisfy debts to creditors. ${ }^{166}$

In theory, if legal personality was not a prerequisite for the appointment of board directors, dominica potestas, actio institoria, actio exercitoria, and actio de in rem verso could provide a body of principles to reckon with when examining the current regulatory gap arising when agency law and laws governing directors' actions cannot be applied due to AI's lack of legal capacity.

More pragmatically, barring statutory requirements for board directors such as being a natural person, accountability is the biggest issue that replacing human directors with artificial intelligence in boardrooms poses. In contrast to scenarios where AI assists human directors or where AI directors share boards with human directors, if artificial intelligence replaces entire boards, there is nobody left to be held accountable. In fact, accountability does not seem to be obtainable without consciousness and a system of internal and external incentives that span from moral laws to monetary remuneration. Proposals that emphasize the role of insurance in order to repair damages caused by artificial intelligence exclusively consider remedies to repair damages caused by lack of accountability but do not address or enhance accountability itself. Accountability requires more than legal capacity; it requires human desires and virtues. It also requires a society able to acknowledge ethics, morals, virtues, and human values. Thus, the greater power AI is afforded in boardrooms, the greater the void of board accountability might be.

\section{CONCLUSION}

Bridging ancient law and contemporary law offers answers to some of the most sophisticated questions in corporate law. Excavating laws and language adopted to address the first corporations allows us to recognize the nature of modern corporations and to trace the origins of corporations' rights and duties. This is helpful in the current debate over rights for corporations on one hand, and it is crucial in understanding the role of separation of ownership and control in the business corporation formula on the other. Further, studying Roman organizational models for business, in particular the negotiation per servos communes cum peculium model, allows us to reckon with arguably the most cutting-edge topic in contemporary corporate governance: the employment of artificial intelligence in boardrooms. Barring the statutory

\footnotetext{
${ }^{165} I d$. at 373.
}

${ }^{166} \mathrm{Id}$. 
restrictions that require for board directors to be natural persons and overcoming the moral concerns related to appointing robo-directors, the ultimate issue surrounding the employment of artificial intelligence in boardrooms is that of accountability. 